\title{
The Policy Innovation in Solving the Conflict Between Online and Conventional Transportation
}

\author{
Riska Wijaya ${ }^{1}$, Kristina Setyowati ${ }^{1,}$ dan Drs. Sudarmo, Ph.D ${ }^{2}$ \\ ${ }^{I}$ Master of public administration, Faculty of Social and Political science, Sebelas Maret University of Surakarta \\ ${ }^{2}$ Lecturer of master of public administration, Faculty of Social and Political science, Sebelas Maret University of Surakarta \\ Wijayariska25@gmail.com,Krist_uns@yahoo.co.id,Sudarmo63@yahoo.com
}

Keywords: Public policy, online transportation, conventional transportation, new media.

\begin{abstract}
Several times ago, the presence of online transportation created a conflict among the government and the users. The presence of online transportation is supposed to replace the cultural values of conventional transportation and carry away the business area of theirs. Moreover, the polemic with the government also happens because the law has not explained the presence of online transportation. In this study, the writer explains the policy innovation that might be reached in solving the conflict. This research uses qualitativedescriptive method. The data was obtained through observation and documentation. The writer analyzed the cases related to the news in electronic media. The conslusion shows that the public understanding on the presence of a new media as the transportation tool is still limited. Moreover, the role of the government in creating the law of transportation innovation has not been finished. It needs a policy or regulation that can manage all aspects in transportation.
\end{abstract}

\section{INTRODUCTION}

People need to move from a place to another place. It becomes a reason that transportation is very essential in human life. The transportation started with the use of human and animal power. As the time went by, the development of transportation becomes more various. Most of them use machine. In Indonesia, vehicle was firstly introduced by John C.Potter. He was an engineer of locomotive who worked in sugar factory of Oemboel, Probolinggo in 1893. After that, any kinds of transportation was developing as the era and technology was in advanced. Now, we know many kinds of transportation that can help people to fill their needs and makes life easier. Recently, people are talking about the new mode of transportation which uses the online application. The presence of online transportation was initiated by the three companies such as GOJEK, GRAB and UBER in 2013. Therefore, it becomes a new topic to discuss in the society.
The presence of online transportation was firstly implemented in Jakarta. Jakarta is a big city that has high mobility. The online transportation was developed as well in other big cities such as Bandung, Surabaya, Yogyakarta, and etc. Transportation innovation is welcomed by the public who have high mobility. The level of efficiency and effectiveness become the main reason for the users to choose online transportation in fulfilling their accomodation. There are many strengths and weaknesses provided by the company of online transportation such as the easy access and interesting vouchers from the partner which has a cooperation with the company. The targets of this service are the customers in big city and have high mobility. The company has been successfully made people interested in using online transportation. Most of the customers are busy with their life and needing the efficiency in their work. Although this service is successful, there are also many problems while running this service. The problem appears from several sides such as from government and the users of conventional transportation. For example, in its early 
presence, online transportation got a strict threat from the conventional transportation.

The advantages offered by online transportation become the reason for the users to choose it. Online transportation is more effective and efficient. As a result, the drivers of conventional transportation have less passengers and then it affects their income. The refusal also came from the regional government and internal sides of company. This problems made the public confused as the users. Therefore, from all the obstacles, it shown that the government needs to make a wise decision to solve the problems.

The presence of online transportation is as an innovation of technology in transportation development. It becomes an important discussion in this matter. Pribandiono (2016) stated that developing certain effort needs an innovation that can follow the development of era and technology. The effort must not be lost by the time. However, it must not omit the previous values of an effort. In transportation development, it needs innovation that can be accepted by the public. It must be beneficial. There are several problems that must be solved in the policy of online transportation;

1. How is the position of online and conventional transportation in public and law?

2. What is the right policy to solve the problems?

\section{METHODS}

In this research, the writer wants to give a description about the position of transportation in public and how it should be in the law. The writer wants to find the solution and solve the conflict using the explanation of the presence of new media as the innovation in making the transportation advanced.

This research used qualitative-descriptive approach and literary study in getting the data information to solve the problems. The writer analyzed the cases through electronic media and real cases as the additional materials.

\section{RESULTS AND DISCUSSIONS}

Transportation based on application (online transportation) has been a part of most people who live in big city which is the place of technology development in society. The interest of people in big city on online transportation has not been able to be accepted widely because the public understanding on a new media is limited. Therefore, its presence creates a polemic.

\subsection{The position of conventional and online transportation in public}

Transportation has become an essential thing in society. The system of public transportation is created to bring the welfare in all aspects in human life. In this millenial era, both kind of transportations (conventional and online) are very important in policy consideration concerning with the transportation system in Indonesia.

\subsubsection{Public as the users of public transportation}

Society as the users of public transportation will choose kind of transportation which is suitable with their needs. As a user, they will search the best transportation by considering the comfort, facility and reasonable price. The presence of online transportation can be a right solution because the public want" to have a fast, precise and economical transportation. Therefore, its presence is welcomed by the public. Anis Agustin in her research entitled "the public perception towards online transportation (GOJEK) in Surabaya" (2017) indicated that positive response of online transportation has been accepted in Surabaya. It is also supported with interesting marketing system for the users.

\subsubsection{Public as the drivers of public transportation}

In providing public transportation, it needs many human resources as the doers and providers. Both conventional and online transportation are operated by the human. The existence of conventional 
transportation has been available since long time ago. Its presence has special value in society such as the association of ojek drivers. However, the value of conventional transportation is not always positive. Putra (2015) stated that the association of ojek drivers are for the community and it is not for the people outside the association. Online transportation has been accepted by the public because of several reasons. It creates big motivation to the public to join the company as a driver. Many people choose to join Uber and Gojek because the company gives more profits. However, the profit is also not received by several workers because they must share their income with the company of Uber and Gojek (Pribandiono, A, 2016)

\subsection{The position of conventional and online tranportation in law}

Based on the law number 22 year 2009 about traffic and road transportation in article 1 paragraph 21, "public transportation company is a law agency which provides the service of public transportation using public vehicles." In article 2, traffic and road transportation must be conducted by considering several principle such as; a. Transparency; b. Accountability; c. Continuity; d. Participative; e. Useful; f. Efficiency and Effectiveness; g. Balance; h. Integrity; i. Independence. Concerning with the explanation of public transportation in PP number 41 year 1993 about public transportation, it stated that public administration using public transportation is conducted using car bus or passenger car. By using the law, the company of transportation makes a policy on conventional or online method. Transportation of bus, train and taxi has been regulated its existence and operation. It emerges a controversy when ojek is illegal in law. The existence of ojek has helped the public. However, not all people know that ojek has not owned legal permission.

Online ojek such as Go-Ride, Grab-Bike, and Uber is not recommended as a legal transportation for the passengers. It has been writen in the law of traffic and road transportation number 22 year 2009 about public transportation of human and stuff that ojek does not belong to public transportation. The polemic of online ojek is still continuing. The court of constitution refused the request of material test number 41/PUU-XVI/2018 proposed by the driver of online ojek (Tempo.co, 29 Juni 2018). Both conventional and online transportation are managed by the company of transportation. If the company has been approved in law, it has the same position in law.

\subsection{Policy innovation and implementation of public transportation system}

In implementing public policy, there are three principles of public administration that can be used as reference called 3E; efficiency, effectiveness and economic. The implementation of policy and public transportation system must also consider the three principles above. If the principles are implemented, the basic principles of efficiency and social justice will be reached (both will be the basis of moral guidance and actors' etiquette) (Setyoko, 2011:36).

In this millenial and openness era, the presence of new media in all aspects of life is a common thing. The presence of new media in public transportation system can be a new way. A development must be followed by the readiness of the actors. If the readiness has been achieved, public transportation innovation will be an efficient and fair policy. Yet, if it is not followed by the readiness, the policy will be in vain. Therefore, it needs to implement the understanding of new media to the people as the supporting tool of public transportation system such as online transportation.

The problems of online transportation in several big cities in Indonesia are a real proof that government and society are not ready to face the presence of new media as supporting tools. The public perception shows that they feel satisfied with the innovation. However, they do not know whether the 
transportation has been legal in law or not. The drivers and company as the provider of online transportation service must obey the regulation. F.X. Hadi Rudyatmo as the mayor of Solo had ever refused online transportation in Solo (news.detik.com, 11 Juli 2017). Although there is no permission, the drivers still operating in Solo. The follow up of illegal activity has been conducted, but most of people still have interest in this kind of innovation. Nowadays, online transportation in Solo becomes a favorite transportation and the number of the users has increased.

The different perception in viewing the problem becomes a problem regarding the process of making the policy which is appropriate with the basic principle of public administration (efficient and fair). The government has important role in determining public policy related to transportation in which it must be fair and legal. The understanding of new media becomes a way to help people to understand the related policy by implementing important values of new media. It can be taken from the digital application of online transportation and other social media.

Therefore, it needs an innovation or clear regulation in solving the problem. If we see the phenomenon, the problem in transportation is not about who is blamed (facility, price and service). Both kind of transportations have its advantages and disadvantages.

The problem is more about the way to manage the market. The providers will manage the distance, price and qualification of the service. Conventional and online transportation have their own marketing point. But since there is no clear regulation and policy between them then the problems arise. If there is a clear regulation, the problem or conflict can be minimized.

The development of technology and globalization have rapidly increased in the era of information openess. Technlogy is continuosly developing in all aspects. The change of conventional into digital technology is also conducted in several aspects such as jurnalism, trading and banking transaction. Besides that, this development is followed by the needs and human life system which changes into digital media. The point above is supported by the statement of the Ministry of Communication and Information in 2017. The Ministry of Communication and Information stated in 2017 that 143,26 million of 262 million people of Indonesia have accessed the internet. The number are increasing from the previous year. The statement of McLuhan about global village becomes true. The government and the society is not ready to face the new media. It will create negative impact in this nation since not all of the people in the nation understand the concept of new media.

Nowadays, four wheels vehicles (taxi) can be ordered by online system using digital application. It has been provided by the company of online transportation. The presence of online transportation is also implemented in two wheels vehicles such as GOJEK with GoRide, GRAB with Grab-Bike, and Uber. Even though in law section, the two wheels vehicles has not been legal. The number of application users in playstore has reached 10 millions download for GOJEK, 50 millions download for $G R A B$ and 100 millions download for $U B E R$. From this data, it can be known that there are many users of online transportation. The effectiveness and efficiency have created advantages for the users. Meanwhile, the drivers of conventional transportation feel threatened by the presence of online transportation.

From the law perspective, the qualification to order transportation through application belongs to electronic transaction. Ordering online transportation through computer or gadget is a part of legal action. The law relation is a relation between the operator of online transportation and the users who order the service (Agus Pribandiono, 2016). Therefore, online transportation is legal if the company has obtained the permission from the government.

Conventional and online transportation required to use legal transaction tool. Online application is the facilitator and a law subject in transportation. The owner of online 
transportation stated that they do not operate in transportation business but they work on application business. Online transportation only facilitates through the application between the providers and the users (Agus Pribandiono, 2016).

The understanding of the presence of innovation in transportation has not been implemented in several levels in the society especially in lower-middle level. As the service providers of public transportation, the government has important role to educate the public about the presence of new media nowadays. As the stakeholder and policy maker, the government must consider the best solution upon the problem that arises. If the solution is finally found than it can be expected that the presence of online transportation can be beneficial in society.

\section{CONCLUSIONS}

The presence of online transportation as an innovation in transportation aspect can be an advantage and boomerang if it is not followed by the understanding of the use of the new media itself. Therefore, the role of the government is essential in implementing the policy about online transportation system. The government should educate the public as the users or the drivers about the new media. The phenomenon of online transportation needs a policy innovation that can be used to manage the transportation in Indonesia and eliminate the related problem from online transportation.

\section{REFERENCES}

Agustin, A. (2017). Persepsi Masyarakat Terhadap Penggunaan Transportasi Online (GOJEK) di Surabaya'. Jurnal Ilmu dan Riset Manajemen, Vol. 6 No. 9

Bakri, H. (2015). Resolusi Konflik melalui Pendekatan Kearifan Lokal Pela Gandong. The Politics: Jurnal Magister Ilmu Politik Universitas Hasanuddin Vol. 1 No. 1

Blanch, A. K., Boustead, R., Boothroyd, R. A., Evans, M. E., \& Chen, H (2015). The role of conflict identification and management in sustaining community collaboration: Report on a four-year exploratory study'. The Journal of Behavioral Health Services \& Research, 42(3), 324 333.

Brazil, Nozi \& David. (2016). Uber and Metropolitan Traffic Fatalities in the United States. American Journal of Epidemiology $\mathrm{Vol}$ 184, No. 3

Dave Adamson, Richard Bromiley, (2013) "Community empowerment: learning from practice in community regeneration", International Journal of Public Sector Management, Vol. 26 Issue: 3, pp.190-202,

H.B. Sutopo (2002), Metodologi Penelitian Kualitatif. Surakarta : UNS Press

Jaya, Pajar H.I. (2011). Resolusi Konflik dalam Kerja Pengembangan Masyarakat. Jurnal Dakwah, Vol. XI, No. 1 Tahun 2011

Indonesia Report 2015. Respon Kebijakan Terhadap Transportasi Berbasis Aplikasi di Jakarta: Kajian Singkat dan Rekomendasi. The Indonesian Institute: 2016.

Ikhsan \& Simarmata. (2017). Building Customer Rentetion in On-line Transportation. Polish Journal of Management Studies, Vol 15 No 2 (2017)

Kusuma Purba. (2017). Online Motorcycle Taxi Simulation by Using Multi Agent System. International Journal of Applied Engineering Research Vol 2 No.19

Kususma Purba. (2017). Nearest Driver-Fifo Combination Model in Online Motorcycle Taxi Dispatch System. Journal of Theoretical and Applied Information Technology Vol 95. No.22 (2017)

Mahargiono, P (2017). Kontroversi Transportasi Online sebagai Dasar Pembenahan Fasilitas Layanan Penumpang bagi Pelaku Bisnis Transportasi di Surabaya. ISBN 9-789-7936-499-93. STIESIA Surabaya: 2017.

Moleong, Lexy J (2002).Metode Penelitian Kualitatif. Edisi Revisi, Bandung: Remaja Rosdakarya

Neo and Chen (2007). Dynamic Governance: Embedding Culture Capabilities and Change in Singapura. World Scientific Publishing Co. Ltd

Pribandiono, A (2016). Transportasi Online vs Transportasi Tradisional Non-Online persaingan Tidak Sehat Aspek Pemanfaatan Aplikasi oleh Penyelenggara Online. Lex. Jurnalica, Vol. 13 No. 2 
Rayle \& Onesimo. (2017). How Cities use regulation for innovation: the case of Uber, Lyft, and Sidecar in San Francisco. ElsevierScienceDirect, Transportation Research Procedia 25 (2017) 3756-3768

Schröter, B., Sessin-dilascio, K., Meyer, C., Matzdorf, B., Sattler, C., Meyer, A., . . . Wortmann, L. (2014). Multi-level governance through adaptive comanagement: Conflict resolution in a brazilian state park. Ecological Processes, 3(1), 1-13.

Sudarmo. 2009. Elemen-Elemen Collaborative Leadership dan Hambatan-Hambatan Bagi Pencapaian Efektivitas Collaborative Governance. Jurnal Ilmu Administrasi Spirit Publik Volume 5 Nomor 2. FISIP. UNS, Surakarta. 